\title{
Treatment of Chromium Pollution by the Reductase Enzyme Generated by a Chromium-Resistant Bacterium Isolated in Dewatering Sludge
}

\author{
Paul Fabrice Nguema ${ }^{1,2}$, Zejiao Luo ${ }^{1}$, Zachari Mohamadou Mounir ${ }^{4} \& \mathrm{Ma} \mathrm{Jun}^{3}$ \\ ${ }^{1}$ State Key Laboratory of Biogeology and Environmental Geology, Ministry of Education, School of \\ Environmental studies, China University of Geosciences, 388 Lumo Lu, Wuhan 430074, China \\ ${ }^{2}$ Schools of Wood, Water and Natural Resources, Faculty of Agronomy and Agricultural Sciences, University of \\ Dschang, P. O. Box 786, Ebolowa \\ ${ }^{3}$ State Key Laboratory of Urban Water Resource and Environment, School of Municipal and Environmental \\ Engineering, Harbin Institute of Technology, Harbin, 150090, People's Republic of China \\ ${ }^{4}$ Département Hygiène Sécurité Environnement, Institut Universitaire de Technologie, Université de Zinder, BP \\ 656, Zinder \\ Correspondence: Paul Fabrice Nguema, School of Wood, Water and Natural Resource, Faculty of Agronomy and \\ Agricultural Sciences, University of Dschang, P. O. Box 786 Ebolowa, Cameroon. Tel: 237-656-750-184. E-mail: \\ fabricenguema@hotmail.com
}

Received: October 7, 2016

Accepted: November 12, 2016

Online Published: May 5, 2017

doi:10.5539/ijb.v9n3p1

URL: https://doi.org/10.5539/ijb.v9n3p1

\begin{abstract}
An efficient $\mathrm{Cr}$ (VI)-resistant and reducing bacterial strain was successfully isolated in dewatering sludge collected from a sewage treatment plant, and characterized in vitro $\mathrm{Cr}$ (VI) reduction through a reductase enzyme. Phylogenetic analysis using $16 \mathrm{~S}$ rDNA gene sequencing revealed that the newly isolated strain namely Pf-1 was closely related to Bacillus cereus. The strain almost reduced $0.17 \mathrm{mM} \mathrm{Cr}$ (VI) within $24 \mathrm{~h}$ incubation and the presence of different substrates such as glucose, sucrose, or acetate significantly enhanced the reduction rate of $\mathrm{Cr}$ (VI) to Cr (III). However, addition of the same substrate at the stationary phase of the microbial growth increased the reduction rate as well as bacterial growth. Additionally, raising the concentration of thiosulfate in the medium doubled the reduction rate under similar conditions. Assay with different fractions of the cells demonstrated that the reductase enzyme activity was mainly associated with the cytoplasmic fraction. The maximum activity was $23.3 \mu \mathrm{M} \mathrm{h}^{-1} \mathrm{mg}^{-1}$ protein and was obtained at the $\mathrm{Cr}(\mathrm{VI})$ concentration of $2 \mathrm{mM}$. The promising strain can be efficiently employed for bioremediation of $\mathrm{Cr}(\mathrm{VI})$ polluted sites.
\end{abstract}

Keywords: Bacillus cereus Pf-1; reductase enzyme; Cr (VI); Cr (III); dewatering sludge

\section{Introduction}

Chromate compounds containing $\mathrm{Cr}(\mathrm{VI})$ are widely used in a variety of industries such as metal finishing industry, petroleum refinery, leather tanning, iron \& steel industry, inorganic chemical production, pulp production processes, production of chromium metal and explosive (ATSDR, 2012). Cr (VI) is produced as a by-product of these industrial processes and wastewater containing $\mathrm{Cr}(\mathrm{VI})$ have become a well recognized hazard in water pollution control due to extremely toxic, mutagenic and carcinogenic effects on the biological system (Xu et al., 2012). Though chromium exists in several valence states, trivalent chromium $(\mathrm{Cr}$ (III)) and hexavalent chromium $(\mathrm{Cr}(\mathrm{VI}))$ are of major environmental significance because of their stability in natural environment (Kwak et al., 2003). Due to leakage, poor storage and improper disposal by these industries, hexavalent chromium has become one of the most frequently detected contaminant at waste sites. Removal of $\mathrm{Cr}(\mathrm{VI})$ in contaminated effluents is a challenge for the whole scientific community.

Conventional physicochemical methods for removing toxic $\mathrm{Cr}$ (VI) from industrial effluents include chemical precipitation, oxidation or reduction, reverse osmosis, ion exchange, membrane technologies and filtration (Cheung et al., 2006; Ozturk et al., 2009; Sau et al., 2010). However, there are several shortcomings of these methods including consumption of excessive energy, poor removal efficiency, production of large amounts of chemical sludge, in addition to the high cost of chemicals used for $\mathrm{Cr}$ (VI) removal, particularly for the removal of relatively low concentrations of $\mathrm{Cr}$ (VI) (He et al., 2011). 
The maximum achievable Cr (VI) removal efficiency by conventional methods is not sufficient to attain the desired treated effluent quality standard for disposal by the industries. Due to its efficient, affordable, and environmental friendly advantages, biotransformation of $\mathrm{Cr}$ (VI) to $\mathrm{Cr}$ (III) by microorganisms is considered as an alternative viable option for the remediation of $\mathrm{Cr}$ (VI) pollution (Sarangi et al., 2008).

Cr (VI) biotransformation also produces Cr (III) - organic complexes with insoluble Cr (III) compounds. Chartterjee et al. (2009) reported that once Cr (III) - organic complexes are formed; they are relatively stable and recalcitrant in short-term biodegradation. In this way, $\mathrm{Cr}$ (III) - organic compounds are known as stable chromium species in the environment and taking part in natural biogeochemical cycle of the chromium.

Several bacterial strains including Bacillus have been shown to reduce toxic and soluble $\mathrm{Cr}$ (VI) to the less toxic and less soluble $\mathrm{Cr}$ (III) through enzymatic reaction (Puzon et al., 2002; Puzon et al., 2005; Ibrahim et al., 2012). However, a few of them can effectively produce the enzyme reductase responsible of $\mathrm{Cr}$ (VI) reduction. In this manuscript we investigated the potentials of the current strain to reduce $\mathrm{Cr}$ (VI) through reductase enzyme as well as the effect of different substrates in the reduction rate. Our results were compared to the previous isolated Bacillus strains. The current study could be helpful to the scientific community since bacteria are widely distributed in nature; screening of reductase enzyme producing strains from the contaminated source is not a difficult task.

\section{Materials and methods}

\subsection{Chemicals}

All the chemicals were of reagent grade and were used without further purification. Unless otherwise stated, all the chemicals were purchased from Sinopharm Group Chemicals Reagents Co. Ltd., Shanghai, China, Fisher (Fair Lawn, Nanjing), and Tianjin Fu Chen Chemical Reagents factory, Tianjin, China.

\subsection{Bacterial Strain, Identification and Growth Conditions}

The bacterial strain, Pf-1 tolerant to $\mathrm{Cr}$ (VI) was isolated in dewatering sludge collected from a sewage treatment plant, Wuhan, China by enrichment culture technique (Nguema et al., 2014). The culture was grown in Nutrient Broth (NB) agar plates previously sterilized amended with $1 \mathrm{mM} \mathrm{Cr}$ (VI) as $\mathrm{K}_{2} \mathrm{Cr}_{2} \mathrm{O}_{7}$. Pf-1 was identified using biomolecular methods. Additionally, the analysis of the nucleotide sequence of $16 \mathrm{~S}$ rDNA gene from Pf-1 was done using Blast-n tools at NCBI (http://blast.ncbi.nlm.nih.gov/Blast.cgi). The phylogenetic tree was constructed by the Neighbor-joining method using MEGA version 5.05 (Tamura et al., 2011).

\subsection{Chromium (VI) Reduction by Isolated Bacillus cereus Pf-1}

The $250 \mathrm{ml}$ conical flasks containing $50 \mathrm{ml} \mathrm{NB}$ (pH $7.0 \pm 0.3$ ) previously sterilized amended with different $\mathrm{Cr}(\mathrm{VI})$ concentrations (0.3-3.4 mM) were inoculated with overnight grown cells of Bacillus cereus. Uninoculated controls (sterilized NB medium + Cr (VI)) were used to compare abiotic $\mathrm{Cr}(\mathrm{VI})$ reduction during experiments. The inoculated cultures along with uninoculated controls were incubated at $30^{\circ} \mathrm{C}$ under orbital shaking $(100 \mathrm{rpm})$ and $5 \mathrm{ml}$ samples were withdrawn at different time intervals to monitor growth and $\mathrm{Cr}$ (VI) reduction.

The total chromium concentration in the supernatant was measured after $24 \mathrm{~h}$ incubation to check whether chromium was absorbed by the bacterial cell.

\subsection{Chromium (VI) Reduction Mediated by Different Substrates}

Minimal Salt Medium (MSM) as previously used by Zacharia et al., 2007 was amended with different $\mathrm{Cr}$ (VI) concentrations (0.1-2 mM) and was supplemented with glucose, sucrose, acetate $\left(\mathrm{C}_{2} \mathrm{H}_{2} \mathrm{NaO}_{2}\right)$, sulfate $\left(\mathrm{Na}_{2} \mathrm{SO}_{4}\right)$ and thiosulfate $\left(\mathrm{Na}_{2} \mathrm{~S}_{2} \mathrm{O}_{3}\right)$ at final concentration of $0.2 \mathrm{mM}$. The $\mathrm{Cr}(\mathrm{VI})$ reduction was initiated after inoculation of culture flaks with Pf-1 strain and the reduction as well as growth was monitored from samples withdrawn at different time intervals. Control experiments (sterilized MSM medium $+\mathrm{Cr}$ (VI) were run in parallel without any substrate added.

\subsection{Extraction of Reductase Enzyme}

Bacillus cereus was cultured in sterilized MSM medium (pH 7.0) amended with glucose $(0.2 \mathrm{mM})$ and $1 \mathrm{mM} \mathrm{Cr}$ (VI); the reaction was incubated at $30^{\circ} \mathrm{C}$ under orbital shaking $(100 \mathrm{rpm})$ for $24 \mathrm{~h}$. At the end of incubation, the cells were centrifuged at $10,000 \times \mathrm{g}$ for $5 \mathrm{~min}$ and the pellets obtained were washed three times with $50 \mathrm{mM}$ phosphate buffer ( $\mathrm{pH} \mathrm{7.2)}$ and re-suspended in $5 \mathrm{ml}$ of buffer. These cell suspensions were placed in an ice bath and disrupted using ultrasonic probe for $2 \mathrm{~h}$. The power was supplied 5 times in 1-min pulse at $50 \mathrm{~W}$. The cell suspensions were centrifuged at $10,000 \times \mathrm{g}$ for $5 \mathrm{~min}$ and the cell pellets were discarded. The supernatant was centrifuged at $160,000 \times \mathrm{g}$ for $1 \mathrm{~h}$ at $4^{\circ} \mathrm{C}$, followed by filtration through $0.22 \mu \mathrm{m}$ filters and the supernatant or the cytoplasmic fraction or cell-free extract (CFE) thus obtained was used as source of soluble enzyme. The pellet or 
cell membrane fraction (CM) was re-suspended in buffer. Aliquots $(1 \mathrm{ml})$ of CFE and CM were used for the enzyme assay in order to localize the reductase enzyme.

\subsection{Analytical Methods}

Pf-1 growth was monitored by standard, or viable, plate count method.

Diphenylcarbazide method (APHA, 1998) using UV visible spectrophotometer with a detection limit of $1.7 \times 10^{-4} \mathrm{mM}$ was used to estimate the $\mathrm{Cr}(\mathrm{VI})$ concentration in the supernatants.

Protein concentrations of the CFE and CM were measured using Bradford reagent (Bradford, 1976) and Bovine serum albumin (BSA) was used as standard protein.

The enzyme assays were performed as previously described Pal et al. (2005). The reaction mixture containing $\mathrm{Cr}$ (VI) at the final concentration of $0.1 \mathrm{mM}$ and $2 \mathrm{mM}$, glucose $(0.2 \mu \mathrm{M})$ in $50 \mathrm{mM}$ phosphate buffer and $1 \mathrm{ml}$ of enzyme reductase.

The total chromium in the samples was analyzed by Atomic Absorption Spectrometry (AAS- Pgeneral TAS-990, Beijing Purkinjie General Instrument Co. Ltd). Chromium standard solutions were prepared by using appropriate dilution of stock $\mathrm{Cr}$ (VI) standard solution for AAS analysis. Limit of detection calculated on a $3 \mathrm{~s}$ basis (a value three times the standard deviation of the blank) was $1 \times 10^{-6} \mathrm{mM} \mathrm{Cr}$

Each experiment was done in triplicate and the difference in their individual results in each set was less than 5\%. The error bars shown in figures represent the standard deviation, calculated using Origin pro software 8.5.

The range of the concentrations chooses in this manuscript was according to the different literature of $\mathrm{Cr}$ (VI) reduction to $\mathrm{Cr}$ (III).

\section{Results}

\subsection{Isolation and Identification of Bacterial Strain}

A Cr (VI)-reducing bacterial strain namely, Pf-1 was isolated in dewatering sludge collected from a sewage treatment plant in Wuhan, China. Pf-1 was found to be Gram positive rod-shaped, motile, possesses oxidase and catalase activities and facultative anaerobe. Based on the 16S rDNA gene sequence results, Pf- 1 has been identified as Bacillus cereus with $99 \%$ similarity to the corresponding sequences of Bacillus sp. in the GenBank databases. A phylogenetic tree was constructed using Pf-1 16S rDNA partial sequences from other Bacillus $s p$. The tree showed that the isolate Pf-1 clustered with high confidence to Bacillus cereus (GU321330) and which further confirm the identity of the 16S rDNA sequence with Bacillus sp. (Figure 1). The isolate was submitted to the GenBank with accession number (KC152883).

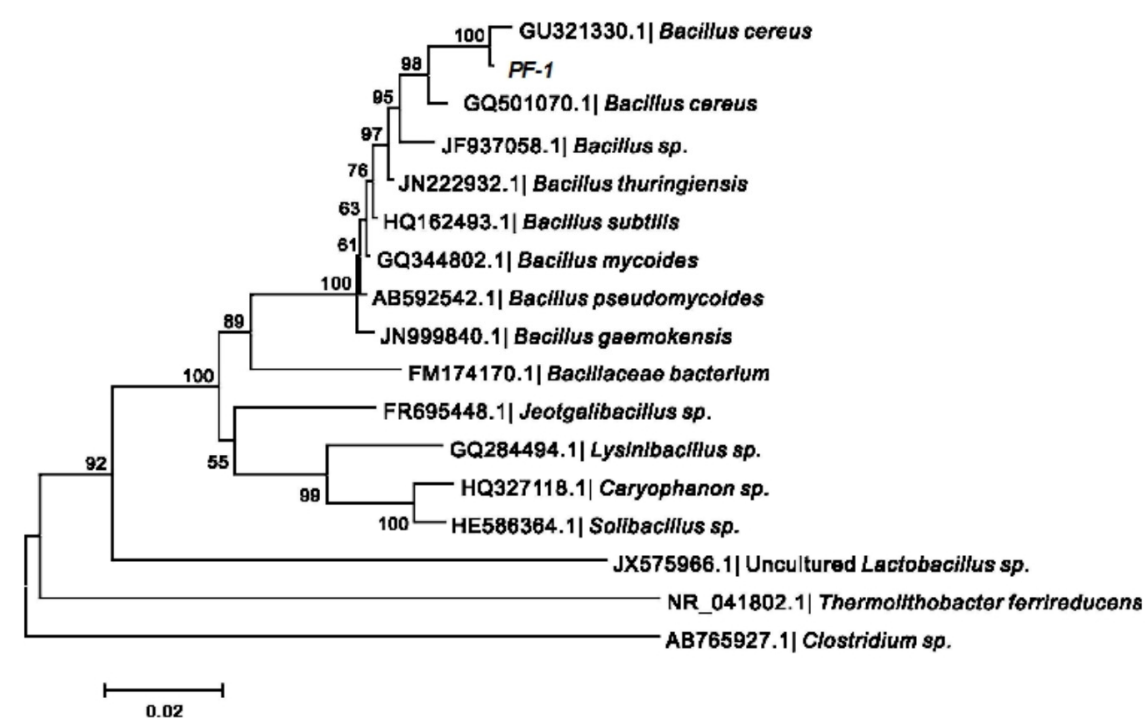

Figure 1. Phylogenetic tree constructed from the 16S rDNA gene of the strain Pf-1 using Neighbor-joining algorithm. Accession numbers are given before the strains name, and scale bar represents 1 base substitution per 20 nucleotide positions. The bootstrap probabilities calculated from 1,000 replications. Clostridium sp. (AB765927) was taken as an out-group 


\subsection{Effect of Initial Cr (VI) Concentration on Growth and Cr (VI) Reduction}

We investigated whether by raising the initial $\mathrm{Cr}(\mathrm{VI})$ concentration in the medium has a significance effect on the cell growth and reduction rate. The results show that the cell growth was affected by the concentration of $\mathrm{Cr}(\mathrm{VI})$ at different levels. The effect is higher at high $\mathrm{Cr}(\mathrm{VI})$ concentration. The Colony-forming Units (CFU) dropped from $5.5 \times 10^{5}$ to $1.1 \times 10^{5}$ when $\mathrm{Cr}(\mathrm{VI})$ concentrations increased from 0.3 to $3.4 \mathrm{mM}$ (Figure 2a). Moreover, the relative reduction rates decreased as the concentrations of $\mathrm{Cr}(\mathrm{VI})$ increased (Figure 2b). The total chromium in the samples remained almost the same at different $\mathrm{Cr}(\mathrm{VI})$ concentrations (Table 1).

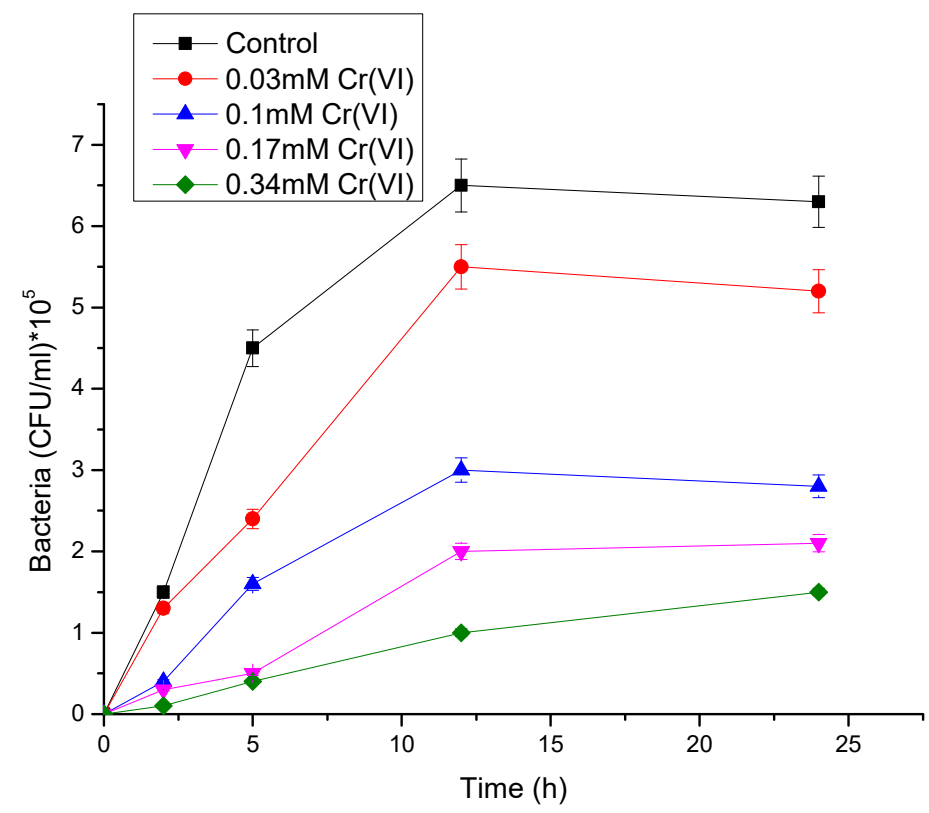

Figure 2a. growth curve of Bacillus cereus in NB medium ( $\mathrm{pH} 7.0)$ amended with different $\mathrm{Cr}(\mathrm{VI})$ concentrations. NB medium ( $\mathrm{pH} 7.0$ ) amended with $0.1 \mathrm{mM} \mathrm{Cr}(\mathrm{VI})$ without bacterial inoculation as a control. Error bars represent standard deviation of triplicate samples

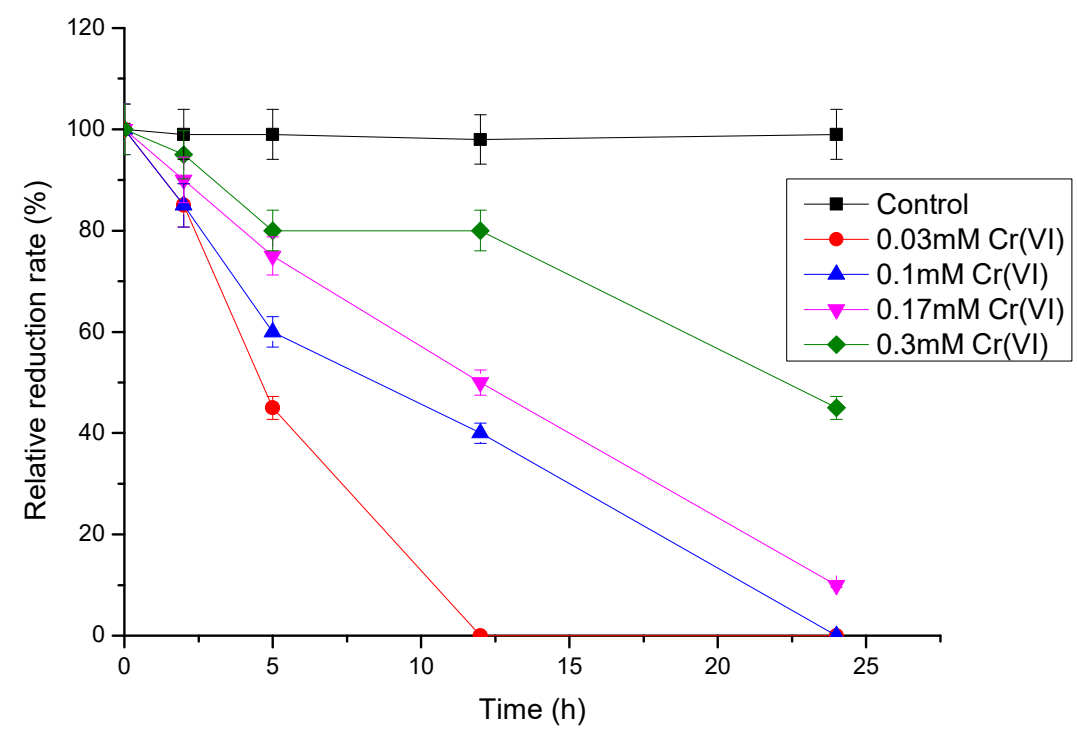

Figure 2b. chromium (VI) reduction by Bacillus cereus $\mathrm{Pf}-1$ in NB medium amended with different $\mathrm{Cr}(\mathrm{VI})$ concentrations. NB medium ( $\mathrm{pH}$ 7.0) amended with $0.1 \mathrm{Mm} \mathrm{Cr}(\mathrm{VI})$ without bacterial inoculation as a control. Error bars represent standard deviation of triplicate samples 
Table 1. Cr(VI) reduction in MSM (pH 7.0) amended with different substrates at concentration of $0.2 \mathrm{mM}$. No substrate was added in the control experiments

\begin{tabular}{lllll}
\hline \multirow{2}{*}{$\mathbf{C r}($ VI) concentrations $(\mathbf{m M})$} & \multicolumn{3}{c}{ Relative rate of reduction $(\boldsymbol{\mu M} / \mathbf{h}) \pm$ standard error } \\
\cline { 2 - 5 } & Glucose & Sucrose & Acetate & Control \\
\hline $\mathbf{0 . 0 1}$ & $0.75 \pm 0.12$ & $0.7 \pm 0.11$ & $0.65 \pm 0.12$ & $0.15 \pm 0.02$ \\
$\mathbf{0 . 0 2}$ & $1.32 \pm 0.41$ & $0.98 \pm 0.2$ & $0.88 \pm 0.15$ & $0.23 \pm 0.12$ \\
$\mathbf{0 . 0 5}$ & $1.98 \pm 0.35$ & $1.53 \pm 0.53$ & $1.1 \pm 0.14$ & $0.29 \pm 0.16$ \\
$\mathbf{0 . 0 7 5}$ & $2.5 \pm 0.13$ & $1.96 \pm 0.3$ & $0.96 \pm 0.16$ & $0.3 \pm 0.13$ \\
$\mathbf{0 . 1}$ & $2.01 \pm 0.11$ & $1.33 \pm 0.36$ & $0.75 \pm 0.17$ & $0.14 \pm 0.11$ \\
$\mathbf{0 . 2}$ & $1.88 \pm 0.23$ & $0.99 \pm 0.2$ & $0.45 \pm 0.33$ & $0.22 \pm 0.17$ \\
\hline
\end{tabular}

\subsection{Cr (VI) Reduction in Presence of Different Substrates}

The relative rates for time (h) versus percentage reduction of $\mathrm{Cr}(\mathrm{VI})$ showed maximum reduction with glucose, followed by sucrose and acetate (Table 1). However, the addition of the same substrate at the stationary phase of the microbial growth increased the rate of bacterial growth as well as $\mathrm{Cr}$ (VI) reduction (Figure 3A and B). Additionally, experiments conducted at $1 \mathrm{mM} \mathrm{Cr}(\mathrm{VI})$ concentration in presence of different concentrations of sulfate and thiosulfate $(0.5-1 \mathrm{mM})$ showed that, in contrast to sulfate, raising the concentration of thiosulfate in the medium doubled the reduction rate under similar conditions (Figure 4A, B, C, and D).

Table 2. Cr(VI) reduction with different fractions of the cells amended with $0.2 \mu \mathrm{M}$ of glucose

\begin{tabular}{lllll}
\hline \multirow{3}{*}{ Fractions } & $\mathbf{0 . 1} \mathbf{m M ~ C r}(\mathbf{V I})$ & \multicolumn{3}{c}{$\mathbf{0 . 2} \mathbf{m M ~ C r}(\mathbf{V I})$} \\
\cline { 2 - 5 } & Enzyme activity $(\mu \mathrm{M}$ & Enzyme activity $(\mu \mathrm{M}$ & Enzyme activity $(\mu \mathrm{M}$ & $\begin{array}{l}\text { Enzyme activity }(\mu \mathrm{M} \\
\end{array}$ \\
& $\mathrm{h}^{-1} \mathrm{mg}^{-1}$ protein) $1 \mathrm{~h}$ & $\mathrm{~h}^{-1} \mathrm{mg}^{-1}$ protein $) 12 \mathrm{~h}$ & $\mathrm{~h}^{-1} \mathrm{mg}^{-1}$ protein $) 1 \mathrm{~h}$ & $\mathrm{~h}^{-1} \mathrm{mg}^{-1}$ protein $) 12 \mathrm{~h}$ \\
\hline Membrane & $7.3 \pm 0.5$ & $11.5 \pm 1.1$ & $4.2 \pm 0.1$ & $10.6 \pm 0.9$ \\
Cytoplasm & $9.6 \pm 0.7$ & $18.6 \pm 1.6$ & $15.6 \pm 1.4$ & $23.3 \pm 1.9$ \\
\hline
\end{tabular}

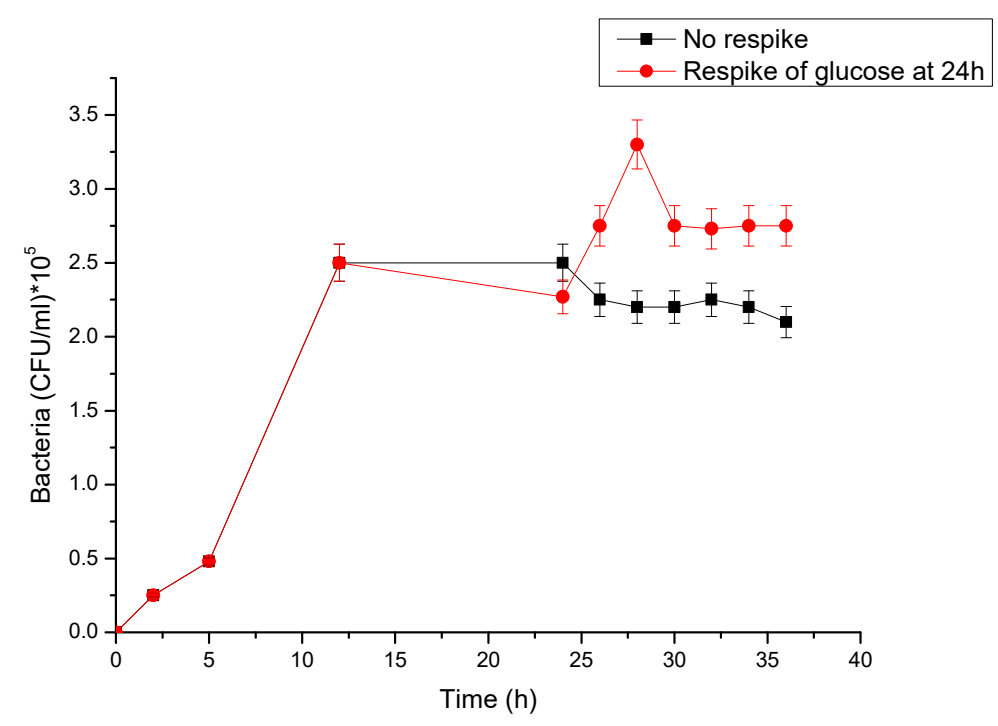

Figure 3a. growth curve of Bacillus cereus Pf-1 in MSM medium (pH 7.0) amended with $0.1 \mathrm{mM} \mathrm{Cr}(\mathrm{VI})$ after glucose was re-spiked during the stationary phase 


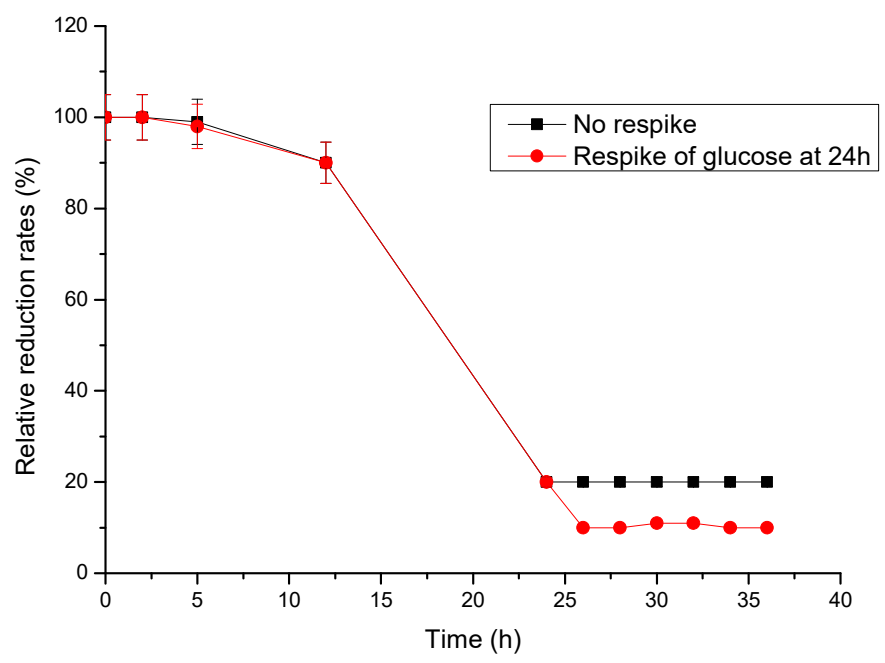

Figure 3b. chromium (VI) reduction of Bacillus cereus $\mathrm{Pf}-1$ in MSM amended with $0.1 \mathrm{mM} \mathrm{Cr}(\mathrm{VI})$ after glucose was re-spiked during the stationary phase

\subsection{Cr (VI) Reduction by Cytoplasmic and Cell Membrane Fraction}

By investigating which fraction of the cell has a higher enzyme activity, we found that the activities were higher with the cytoplasmic fraction at different time intervals and at different $\mathrm{Cr}(\mathrm{VI})$ concentrations (Table 2). Moreover, the enzyme activity also increased as the initial $\mathrm{Cr}$ (VI) concentration increased. Higher activity $\left(23.3 \mu \mathrm{M} \mathrm{h}^{-1} \mathrm{mg}^{-1}\right.$ protein) could be obtained at higher $\mathrm{Cr}(\mathrm{VI})$ concentration $(2 \mathrm{mM})$, at $30^{\circ} \mathrm{C}$ and $\mathrm{pH} 7$. Previous experiments conducted at different temperature $\left(10-65^{\circ} \mathrm{C}\right)$ and $\mathrm{pH}(5-9)$ showed the maximum activity at $30^{\circ} \mathrm{C}$ and $\mathrm{pH} 7$, respectively (Data not shown). Considering the reductase enzyme activity at $30^{\circ} \mathrm{C}$ as $100 \%$, the reductase enzyme activity of Pf- 1 at lower temperature of $10^{\circ} \mathrm{C}$ and higher temperature of $65^{\circ} \mathrm{C}$ decreased by $44 \%\left(13.1 \mu \mathrm{M} \mathrm{h}^{-1} \mathrm{mg}^{-1}\right.$ protein) and $57 \%\left(10 \mu \mathrm{M} \mathrm{h}^{-1} \mathrm{mg}^{-1}\right.$ protein), respectively. Considering also the activity at $\mathrm{pH} 7$ as $100 \%$, the reductase enzyme activity of Pf-1 at different $\mathrm{pH}$ was determined. At $\mathrm{pH} 5$ and 9 , the specific activities were decreased by $32 \%\left(15.9 \mu \mathrm{M} \mathrm{h}^{-1} \mathrm{mg}^{-1}\right.$ protein) and $14 \%\left(20.1 \mu \mathrm{M} \mathrm{h}^{-1} \mathrm{mg}^{-1}\right.$ protein), respectively.

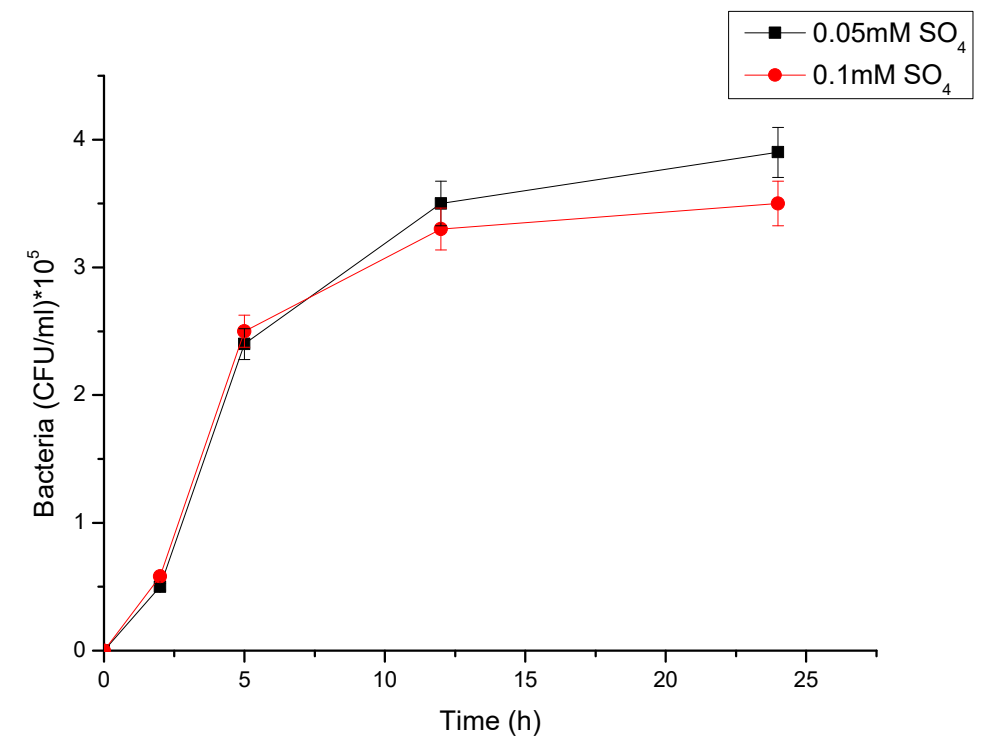

Figure 4a. growth curve of Bacillus cereus Pf-1 in MSM medium (pH 7.0) amended with different sulfate concentrations and $0.1 \mathrm{mM} \mathrm{Cr}(\mathrm{VI})$ 


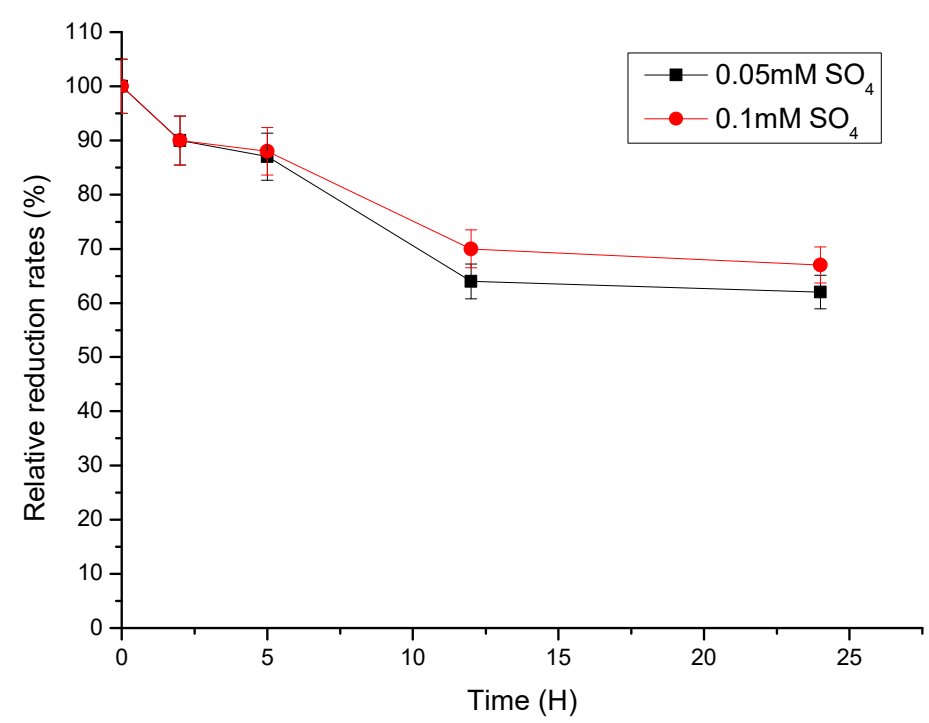

Figure 4b. chromate reduction of Bacillus cereus Pf-1 in MSM medium (pH 7.0) amended with different sulfate concentrations and $0.1 \mathrm{mM} \mathrm{Cr}(\mathrm{VI})$

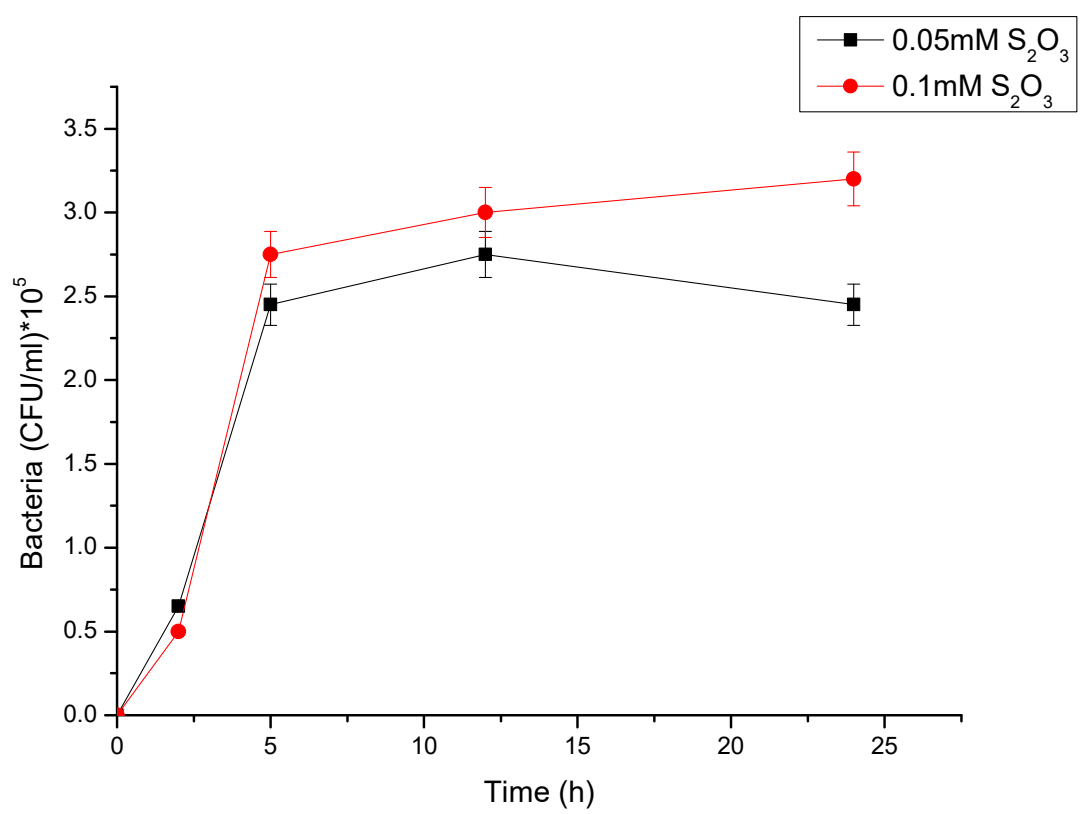

Figure 4c. growth curve of Bacillus cereus Pf-1 in MSM medium (pH 7.0) amended with different thiosulfate concentrations and $0.1 \mathrm{mM} \mathrm{Cr}(\mathrm{VI})$ 


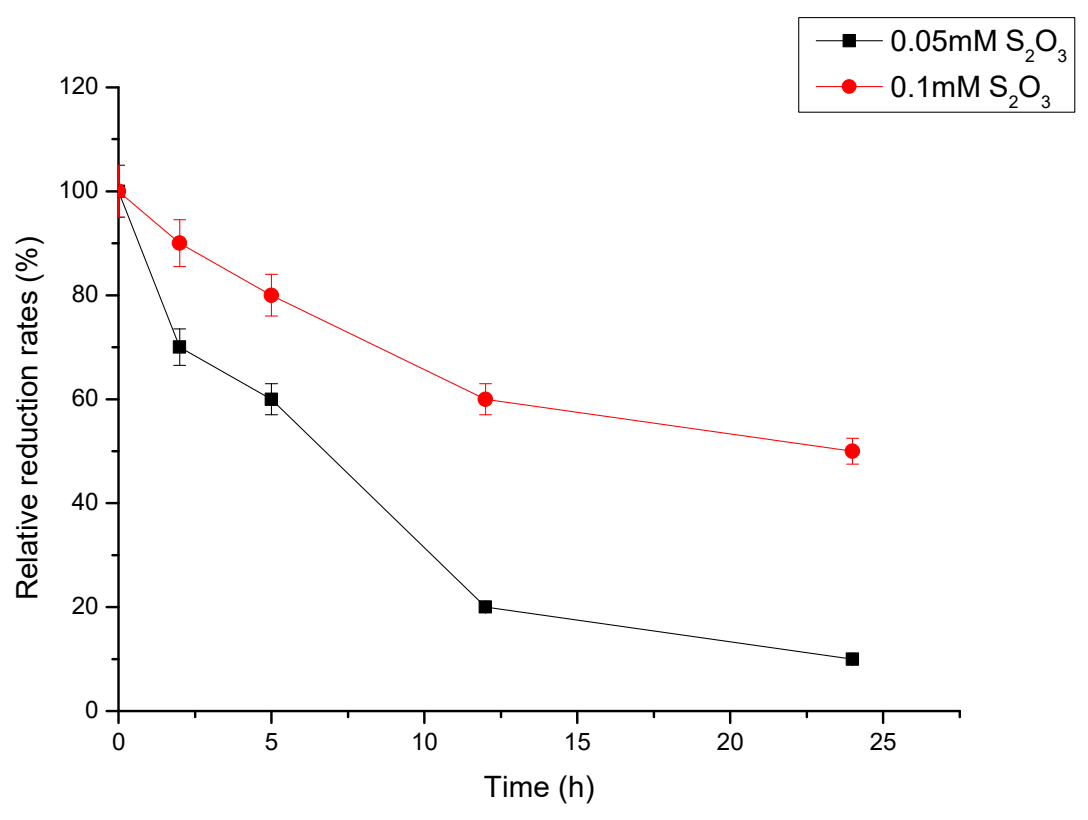

Figure 4d. chromium (VI) reduction of Bacillus cereus Pf-1 in MSM medium (pH 7.0) amended with different thiosulfate concentration. $\mathrm{Cr}(\mathrm{VI})$ concentration in the medium was $0.1 \mathrm{mM}$

\section{Discussion}

We have isolated a chromium-resistant and reducing bacterium from dewatering sludge and identified as Bacillus cereus. Therefore, the ability of the isolate to reduce $\mathrm{Cr}(\mathrm{VI})$ through reductase enzyme was investigated.

The investigation showed that Bacillus cereus grew well in the presence of different $\mathrm{Cr}$ (VI) concentrations and could almost reduce these concentrations within $24 \mathrm{~h}$ incubation, suggesting that Pf-1 strain has a strong reducing capability. Strains of genus Bacillus are known to tolerate and reduce Cr (VI) (Campos et al., 1995; Liu et al., 2006; Soni et al., 2013). The tolerance level of Cr (VI) for our newly isolated strain of Bacillus cereus was $3.4 \mathrm{mM}$; which is more than other strain of Bacillus cereus those have been known to tolerate $2 \mathrm{mM} \mathrm{Cr}$ (VI) (Sarangi and Khrishan, 2008). However, a hyper-resistant Bacillus sp. ES29 has been reported who is resistant to very high level of $\mathrm{Cr}(\mathrm{VI})$ at $>9.6 \mathrm{mM}$ (Camargo et al., 2003b). In our experiments, higher $\mathrm{Cr}(\mathrm{VI})$ concentration $(3.4 \mathrm{mM})$ caused decrease in growth rate when compared to growth at lower concentrations; this was ascribed to the toxic effect of $\mathrm{Cr}(\mathrm{VI})$. Toxic effect of $\mathrm{Cr}(\mathrm{VI})$ on the cell growth at higher concentration has been mentioned in the literature (Pal et al., 2005; Cheng and Li, 2009). Further, the total chromium remained almost the same at different Cr (VI) concentrations and this suggests that the decrease of $\mathrm{Cr}(\mathrm{VI})$ concentration in the supernatant was the effect of reduction of $\mathrm{Cr}$ (VI) to $\mathrm{Cr}$ (III) and not adsorption (Pal et al., 2005).

It is also evident from our results (Figure 2b) that increase in chromate reduction was growth dependent; higher reductions were noticed during the first $12 \mathrm{~h}$ corresponding to the exponential phase of the microbial growth. Most likely, bacteria growth and $\mathrm{Cr}(\mathrm{VI})$ reduction induced-damage are competing processes, and bacteria can cope with $\mathrm{Cr}$ (VI) exposure only as long as carbon sources are available. However, the addition of carbon sources such as glucose, sucrose or acetate in the media significantly enhances the reduction rate, suggesting the utilization of these carbon sources by Bacillus cereus.

Addition of the same substrate at the stationary phase (24h) of Bacillus cereus significantly enhances Cr (VI) reduction to $\mathrm{Cr}$ (III) as well as cell growth. In general, the stationary phase corresponding to the depletion of carbon sources and the necessary energy for the microbial growth, the addition of energy source such as glucose will reactivate the metabolism of the microorganism and this will have a positive effect on the bacterial growth as well as $\mathrm{Cr}(\mathrm{VI})$ reduction.

Meanwhile, in contrast with sulfate, raising the concentration of thiosulfate in the medium doubled the reduction rate of $\mathrm{Cr}$ (VI) to $\mathrm{Cr}$ (III) under similar conditions (Figure 5). However, a similar effect was not observed with the cell growth. In this regard, thiosulfate uptake was through bacterial cell wall or membrane which enhances the 
biosynthesis of the reductase enzyme and enables the reduction of $\mathrm{Cr}$ (VI) to Cr (III). Moreover, all living organisms require sulfur for the synthesis of proteins and essential cofactors. Sulfur could be assimilated either from inorganic sources, such as sulfate and thiosulfate, or from organic sources, such as sulfate esters for example. It has been shown in the literature that sulfur is transported into the cell via an ATP-binding cassette-type sulfate-thiosulfate system (Guilouard et al., 2002). Our results can also corroborate with their finding.

The results on the assay with different fractions of the cell showed that the reductase enzyme was more active and more efficient in the cytoplasmic fraction. Therefore, it could be concluded that the reductase enzyme generated by Bacillus cereus may be primarily intracellular. Reports associate the reductase enzyme with cytoplasmic fraction of Providencia sp., Bacillus sp. and Microbacterium sp. were recently investigated (Pal et al., 2005; Thacker et al., 2006; Soni et al., 2013). The enzyme activity reported by Desai and his coworkers (2008) were lower compared to the values obtained in our experiments at the same $\mathrm{Cr}$ (VI) concentration, suggesting that our strain is a higher reductase producing bacterium among Bacillus strains reported up to date (Table 2). Moreover, the enzyme activity was affected by the temperature and $\mathrm{pH}$ of the medium. The temperature below and above $30^{\circ} \mathrm{C}$ decreased the enzyme activity, suggesting that the enzyme was affected by the temperature. The observation was made with the $\mathrm{pH}$, having the maximum activity at $\mathrm{pH}$ 7. Similar observations of the influence of temperature and $\mathrm{pH}$ in the enzyme activity have been made in the literature (Pal et al., 2005; Desai et al., 2008). Suziki et al. (1992) reported that some bacteria were known to use chromate as a terminal electron acceptor employing membrane bound enzymes, while others use soluble enzymes. Negligible reduction was noticed in abiotic control indicating the direct interaction of the cell in $\mathrm{Cr}(\mathrm{VI})$ reduction. Similar results indicating negligible reductions in abiotic control have been earlier reported by (Massod \& Malik, 2011; He et al., 2010).

\section{Conclusion}

The results of the current study clearly demonstrate that Bacillus cereus Pf-1 has strong potentialities to reduce toxic $\mathrm{Cr}$ (VI) to the less toxic $\mathrm{Cr}$ (III) through enzyme reductase and hence can be considered as a reductase producing strain. Additionally, Bacillus cereus $\mathrm{Pf}-1$ can be employed as a bio-agent for chromium detoxification from the contaminated effluents. Since bacterial growth is rapid, we could produce the reductase enzyme in $24 \mathrm{~h}$ by providing nutrient and trace amount of chromate. Further, industrial symbiosis approach would be a feasible option; wastewater from food industries could be used as energy source for bacterial growth and reductase production.

\section{Acknowledgements}

This research was jointly supported by the National Natural Science Foundation of China (No: 40872157, 40830748); National Program on Key Basic Research Project of China (973 Program) (No: 2010CB428802).

\section{References}

ATSDR. (2012). Toxicological profile for Chromium Atlanta, GA: U.S. Department of Health and Human Services, Public Health Service

APHA. (1998). Standard Methods for the Examination of Water and Wastewater (19 ${ }^{\text {th }}$ ed.), Washington DC

Bradford, M. M. (1976). A rapid and sensitive method the quantification microgram quantities of proteins utilization the principle of protein-dye binding. Analytical Biochemistry, 72(1-2), 248-254

Cheng, G., \& Li, X. (2009). Bioreduction of Cr (VI) by Bacillus sp. isolated from soil of iron mineral area. European Journal of Soil Biology, 45(5-6), 483-487. http://dx.doi.org/10.1016/j.ejsobi.2009.06.009

Cheung, K. H., Lai, H. Y., \& Gu, J. D. (2006). Membrane associated hexavalent chromium reductase of Bacillus megaterium TKW3 with induced expression. Journal of Microbiology and Biotechnology, 16(6), 855-862. http://dx.doi.org/10.1155/2013/909412

Chatterjee, N., \& Luo, Z. (2009). Effect of two different Cr (III)-organic compounds exposure to Saccharomyces cerevisiae. Toxicological and Environmental Chemistry, 92, 75-88. http://dx.doi.org/10.1080/02772240 902830763

Compos, J., Martinez-Pacheco, M., \& Cervantes, C. (1995). Hexavalent chromium reduction by a chromate resistant Bacillus sp. strain. Antonie Van Leeuwenhoek, 68(3), 203-208. doi:10.1007/BF00871816

Camargo, F. A. O., Okebe, B. C., Bento, F. M., \& Frankenberger, W. T. (2003b). In vitro reduction of hexavalent chromium by a cell free extracts of Bacillus sp. ES 29 stimulated by $\mathrm{Cu} 2+$. Applied and Environmental Biotechnology, 62, 569-573. http://dx.doi.org/10.1007/s00253-003-1291-x 
Desai, C., Jain, K., \& Madamwar, D. (2008). Evaluation of in vitro Cr (VI) reduction potential in cytosolic extracts of three indigenous Bacillus sp. isolated from $\mathrm{Cr}(\mathrm{VI})$ polluted industrial landfill. Bioresource Technology, 99, 6059-6069. http://dx.doi.org/10.1016/j.biortech.2007.12.046

Guillouard, S., Auger, S., Hullo, M. F., Chetouani, F., Danchin, A., \& Verstraete, I. M. (2002). Identification of Bacillus subtilis Cysl, a regulator of the Cysjl operon, which encodes sulfite reductase. Journal of Bacteriology, 184(17), 4681-4689. http://dx.doi.org/10.1128/JB.184.17.4681-4689.2002

He, M., Li, X., Liu, H., Miller, S. J., Wang, G., \& Rensing, C. (2010). Characterization and genomic analysis of a highly chromate resistant and reducing bacterial strain Lysinibacillus fusiformis ZC1. Journal of Hazardous Materials, 185(2-3), 682-688. http://dx.doi.org/10.1016/j.jhazmat.2010.09.072

He, M., Li, X., Guo, L., Miller, S., Rensing, C., \& Wang, G. (2010). Characterization and genomic analysis of chromate resistant and reducing Bacillus cereus strain SJ1. BMC Microbiology, 10(221), http://dx.doi.org/10.1186/1471-2180-10-221

Ibrahim, A. S. S., El-Tayeb, M. A., Elbadawi, Y. B., Al-Salamah, A. A., \& Antranikian, G. (2012). Hexavalent chromate reduction by alkaliphilic Amphibacillus sp. KSUCr3 is mediated by copper-dependent membrane-associated Cr (VI) reductase. Extremophiles, 16(4), 659-668. http://dx.doi.org/10.1007/s00792 $-012-0464-\mathrm{x}$.

Kwak, Y. H., Lee, D. S., \& Kim, H. B. (2003). Vibrio harveyi nitroreductase is also a chromate reductase. Applied and Environmental Microbiology, 69(8), 4390-4395. http://dx.doi.org/10.1128/AEM.69.8.4390-4395.2003

Liu, Y. G., Xu, W. H., Zeng, G. M., Li, X., \& Gao, H. (2006) Cr (VI) reduction by Bacillus sp. isolated from chromium landfill. Process Biochemistry, 41(9), 1981-1986. http://dx.doi.org/10.1016/j.procbio.2006.04.020

Masood, F., \& Malik, A. (2011). Hexavalent chromium reduction by Bacillus sp. strain FM1 isolated from heavy metal contaminated soil. Bulletin of Environmental Contamination and Toxicology, 86(1), 114-119. http://dx.doi.org/10.1007/s00128-010-0181-z.

Nguema, P. F., Luo, Z., \& Lian, J. J. (2014). Enzymatic chromium(VI) reduction by cytoplasmic and cell membrane fractions of chromate-reducing bacterium isolated from sewage treatment plant. International Journal of Biology, 6(2), 64-76. http://dx.doi.org/10.5539/ijb.v6n2p64

Ozturk, S., Aslim, B., \& Suludere, Z. (2009). Evaluation of Cr (VI) removal behavior by two isolates of Synechocystis sp. in term of exopolysaccharide (EPS) production and monomer composition. Bioresource Technology, 100(23), 5588-5593. http://dx.doi.org/10.1016/j.biortech.2009.06.001 .

Pal, A., Dutta, S., \& Paul, A. K. (2005). Reduction of hexavalent chromium by cell free extract of Bacillus sphaericus AND 303 isolated from serpentine soil. Current Microbiology, 51(5), 327-330. http://dx.doi.org/10.1007/s00284-005-0048-4

Puzon, G. J., Petersen, G. N., Roberts, A. G., Kramer, D. M., \& Xun, L. (2002). A bacterial flavin reductase system reduces chromate to soluble chromium (III)-NAD (+) complex. Biochemistry and Biophysical Research Communications, 294(1), 76-81. http://dx.doi.org/10.1016/S0006-291X(02)00438-2

Puzon, G. J., Roberts, A. G., Kramer, D. M., \& Xun, L. (2005). Formation of soluble chromium (III) complexes after chromate reduction in the presence of cellular organics. Environmental Science and Technology, 39(8), 2811-2817. http://dx.doi.org/10.1021/es048967g

Suziki, T., Miyata, N., Horitsu, H., Kawai, K., Takamizawa, K., Tai, Y., \& Okazaki, M. (1992). NAD (P)H-dependent chromium (VI) reductase of Pseudomonas ambigua G-1: A Cr (V) intermediate is formed during the reduction of $\mathrm{Cr}$ (VI) to $\mathrm{Cr}$ (III). Journal of Bacteriology, 174(16), 5340-5345. http://dx.doi.org/0021-9193/92/165340-06\$02.00/0

Soni, S. K., Rakshapal, S., Ashtosh, A., Mangal, S., \& Alok, K. (2013). In vitro Cr (VI) reduction by cell free extracts of chromate reducing bacteria isolated from tannery effluent irrigated soil. Environmental Science and Pollution Research, 20(3), 1661-1674. http://dx.doi.org/10.1007/s11356-012-1178-4

Sarangi, A., \& Krishnan, C. (2008). Comparison of in vitro Cr (VI) reduction by CFEs of chromate resistant bacteria isolated from chromate contaminated soil. Bioresource Technology, 99(10), 4130-4137. http://dx.doi.org/10.1016/j.biortech.2007.08.059

Sau, G. B., Chatterjee, S., \& Mukherjee, S. K. (2010). Chromate reduction by cell free-extract of Bacillus firmus KUCr1. Polish Journal of Microbiology, 59(3), 185-190. 
Thacker, U., Parikh, R., Shouche, Y., \& Madamwar, D. (2006). Hexavalent chromium reduction by Providencia sp. Process Biochemistry, 41(6), 1332-1337. http://dx.doi.org/10.1016/j.procbio.2006.01.006

Tamura, K., Peterson, D., Peterson, N., Stecher, G., Nei, M., \& Kumar, S. (2011). MEGA5: Molecular Evolutionary Genetics Analysis using maximum likelihood, evolutionary distance, and maximum parsimony methods. Molecular Biology and Evolution, 28(10), 2731-2739. http://dx.doi.org/10.1093/molbev/msr121

Xu, L., Luo, M., Jiang, C., Wei, X., Kong, P., Liang, X., Zhao, J., Yang, L., \& Liu, H. (2012) in vitro reduction of hexavalent chromium by cytoplasmic fractions of Pannonibacter phragmitetus LSSE-09 under aerobic and anaerobic conditions. Applied Biochemistry and Biotechnology, 166(4), 933-941. http://dx.doi.org/10.1007/ s12010-011-9481-y

Zacharia, Z. A., Zacharia, Z., Surif, S., \& Ahmad, W. A. (2007). Hexavalent chromium reduction by Acinetobacter haemolyticus isolated from heavy-metal contaminated wastewater. Journal of Hazardous Materials, 146(1-2), 30-38. http://dx.doi.org/10.1016/j.jhazmat.2006.11.052

\section{Copyrights}

Copyright for this article is retained by the author(s), with first publication rights granted to the journal.

This is an open-access article distributed under the terms and conditions of the Creative Commons Attribution license (http://creativecommons.org/licenses/by/4.0/). 